\title{
Effect of exposure of African catfish (Clarias batrachus) to magnetic field on water properties and egg hatching
}

\author{
Sadam M. Hassan*1, 2, Ridzwan A. Rahman, ${ }^{2,3}$, Rezuan H. Kamaruddin ${ }^{2}$ and Najilaa S. Madlul 4 \\ ${ }^{1}$ Department of Animal Production, College of Agriculture, University of Tikrit, Salah Al-deen, Iraq. \\ ${ }^{2}$ School of Bioprocess Engineering, University Malaysia Perlis, Jejawi 3, 02600 Arau, Perlis, Malaysia. \\ 3 Institute of Sustainable Agrotechnology (INSAT), 7, 02100 Padang Besar, Perlis, Malaysia. \\ ${ }^{4}$ Department of Agriculture Economic, College of Agriculture, University of Tikrit, Salah Al-deen, Iraq.
}

${ }^{*}$ Corresponding author: saddamiraq1981@gmail.com.

\begin{abstract}
Magnetic water is produced when water is passed through a magnetic field with the purpose of modifying its structure. The changes in physical and chemical properties of magnetised water affect the biological properties of the organisms. The magnetic field can affect the growth of fish from the embryo to the adult stage. The present study evaluates the effects of magnetic field exposure on water properties and hatchability of the eggs of African catfish (Clarias gariepinus). Water was passed through magnetic devices of different intensities; namely: 0.10, 0.15 and 0.20 Tesla. The dissolved oxygen $\left(\mathrm{mgL}^{-1}\right)$ and $\mathrm{pH}$ levels were found to significantly $(\mathrm{P} \leq 0.05)$ increase from $5.92 \mathrm{mgL}^{-1}$ to $6.33 \mathrm{mgL}^{-1}$, and from 8.03 to 8.19 , respectively. Ammonium ( $\left.\mathrm{NH}_{4}-\mathrm{N} \mathrm{mgL}^{-1}\right)$ level declined significantly $(\mathrm{P} \leq 0.05)\left(0.20 \mathrm{mgL}^{-1}\right.$ to $\left.0.16 \mathrm{mgL}^{-1}\right)$. Salinity (ppt), conductivity (uscm$\left.{ }^{1}\right)$, specific conductance (uscm$\left.{ }^{-1}\right)$ and total dissolved solids $\left(\mathrm{mgL}^{-1}\right)$ also decreased after magnetization. Significant increase in the rate of hatching was attained in water exposed to a magnetic field of $0.10,0.15$ and $0.20 \mathrm{~T}$. The study demonstrated the benefits of using magnetic devices that are simple, practical and cost-effective.
\end{abstract}

Keywords: Magnetic field, Magnetized water, African catfish hatchability, Water properties.

\section{Introduction}

The African Catfish is a widely consumed fish. Ability of this fish to endure rearing conditions and handling makes it the fish of choice in Malaysian restaurants (Olaleye, 2005). Because the fish can breed easily in captivity, it is a great advantage in farming. Janssen (1985) noted that the artificial reproduction of $C$. gariepinus requires enough flow of suitable quality water. De Graaf et al. (1995) reported that the average hatching percentage of the eggs varied between $28.4 \pm 4.5$ and $59.1 \% \pm 3.7$ for catfish, while Macharia et al. (2005) reported a rate of as low as $4 \%$ for the incubated eggs. High rate of fertilization, hatching and survival of larvae at early stage are important factors in the culture of this and other species (Ataguba et al., 2009).

Water quality is determined by variables such as temperature, turbidity, colour, $\mathrm{pH}$, hardness, and the contents of carbon dioxide, unionised ammonia, nitrite and nitrate (Bhatnagar and Devi, 2013). Undesirable water quality can be harmful to aquatic animals. Hence, measures are taken to improve water quality for fish culture.

The magnetic field can affect the growth of fish from the embryo to the adult stage (Chew and Brown, 1989; Tesch et al., 1992; Formicki and Perkowski, 1998; Formicki et al.,
2004 a, b; Tanski et al., 2005; Formicki, 2008). It affects the egg's water uptake after fertilization (Sadowski et al., 2007), motility of developing embryos (Winnicki et al., 2004), embryonic respiration (Formicki et al., 1998), and spatial orientation of embryos and larvae (Formicki et al., 1997). Magnetized (or magnetically treated) water is produced by passing it through a magnetic field of certain strength (Rasoolian et al., 2014). Lund (1947) noted an accelerated growth in plants treated with magnetized water. Since then researchers have used a variety of experimental techniques to study the effects of magnetic field on living organisms. Some studies (Vagra, 1976; Lebkowska, 1991; Baker and Judd, 1996; Gabrielli et al., 2001; Krzemieniewski et al., 2003; Krzemieniewski et al., 2004) have revealed that exposing water to magnetic field influences the water's surface tension, density, viscosity, hardness, conductivity and solubility of solid matter. These changes in properties affect the biology of the organisms that use the water. According to Sunitha and Padmavathi (2013) the high $\mathrm{NH}_{3}$ $\mathrm{N}$ level is detrimental to the fish and thus, a low level of $\mathrm{NH}_{3}-$ $\mathrm{N}$ in treatments is desirable for fish growth. The dissolved oxygen is the crucial parameter of water quality because of its effect on metabolism. Likewise, $\mathrm{pH}$ affects the metabolism and other physiological processes. The improved hatching of the eggs of Tilapia is due to the effect of magnetic fields on ion fluxes, ligand binding and enhanced distribution and aggregation of intramembranous proteins (Bersani et al., 
1997). The water salinity affects Artemia hatchability (Soundarapandian and Saravanakumar, 2009).

The interaction of magnetic energy with water has stimulated research interest for widening the use of magnetized water in various areas, as well as understanding the fundamental mechanisms of such interactions. Gill et al. (2005) noted significant gaps in knowledge regarding the use of magnetized water in aquaculture. There are still many questions pertaining to this topic in aquaculture, such as the intensity of exposure to magnetic field, effects on water properties, and the effects of these properties on aquaculture organisms and many more. This study aims at studying the effects of exposing water to magnetic field on its properties and hatching of the eggs of African catfish.

\section{Materials and Method}

A sequence of procedures was followed to implement the magnetization of water. It involved the usage of a set of magnets with intensities $(0.10,0.15$ and $0.20 \mathrm{~T})$. Devices used are shown in Figures 1 and 2.
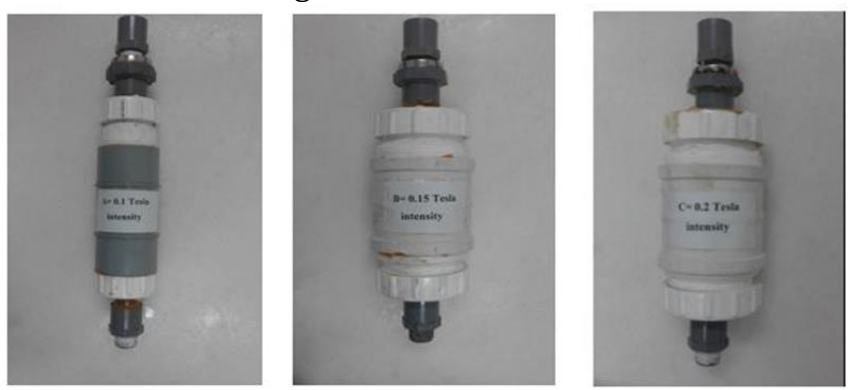

Figure 1. The magnetization devices of different intensities used in the experiment (a) $0.10 \mathrm{~T}$ (b) $0.15 \mathrm{~T}$ (c) $0.20 \mathrm{~T}$.

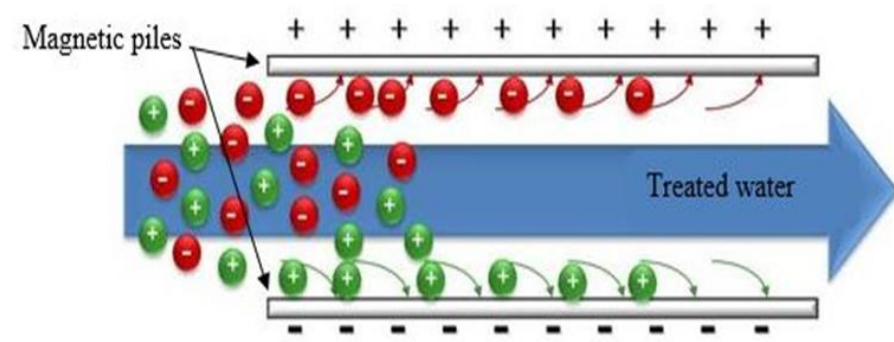

Figure 2. Cross-section of the magnetic devices.

The magnetization of water was carried out at the rate of a single application to the magnetic flux. The professional Plus Multiparameter Water Quality Meter was used to measure water quality parameters. These parameters included water temperature, dissolved oxygen concentration (DO) $\mathrm{mg} \mathrm{L}^{-1}$, pH level, specific conductance (SPC) $\mathrm{uscm}^{-1}$, salinity (SAL) ppt, conductivity (CD) uscm ${ }^{-1}$, total dissolved solids (TDS) $\mathrm{mg} \mathrm{L}^{-1}$, ammonia $\left(\mathrm{NH}_{3}-\mathrm{N}\right) \mathrm{mg} \mathrm{L}^{-1}$, and ammonium $\left(\mathrm{NH}_{4}-\mathrm{N}\right) \mathrm{mg} \mathrm{L}^{-1}$. All these parameters were measured in the control (tap water) and magnetized water at intensities of $0.10,0.15$ and $0.20 \mathrm{~T}$. The study was conducted in the hatchery for a week. Magnetizing of water at three different intensities was carried out by allowing it to flow through one of the three devices containing magnets with different field strengths as follows: $0.10,0.15$ and 0.20 $\mathrm{T}$ (Figure 3). Water was magnetized by running it through the magnetic devices for two days. Parameters observed were: temperature $\left(\mathrm{C}^{\circ}\right)$, dissolved oxygen concentration, $\mathrm{pH}$ level, NH4-N level, NH3-N level, SAL, CD, SPC and TDS.

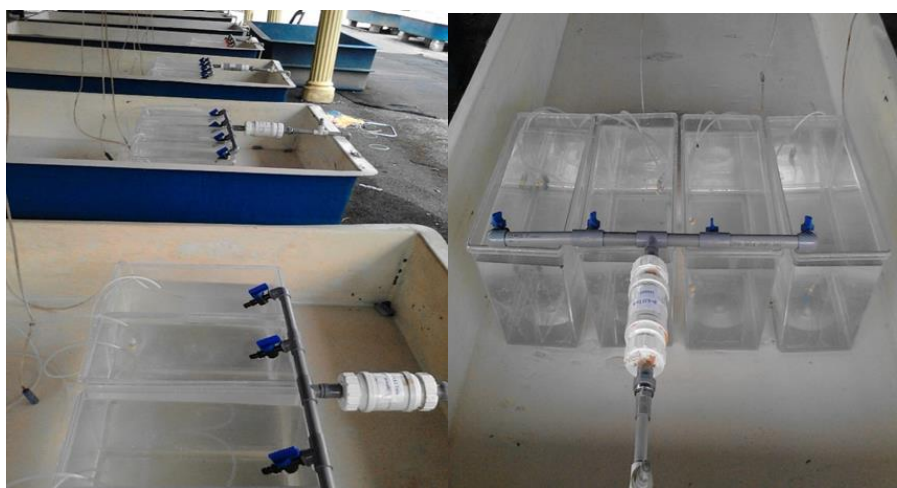

Figure 3. Positions of the magnetic device in the experimental assembly.

\section{Egg incubation}

The broodstock was kept separately without feeding after they were injected with $0.35 \mathrm{ml}$ Ovaprim per kg live weight (Oyeleye and Omitogun, 2007). After $12 \mathrm{~h}$, the female brood stock was taken out and held gently in a wet towel while slight pressure was applied on the abdomen to release the eggs into a dry bowl as suggested by Hogendoorn (1979). The male was sacrificed to obtain the gonads which contained the milt. The mixture of eggs and milt was stirred gently for about $1.0-2.0$ minutes to allow fertilization to take place. Within a few minutes, the eggs absorbed water and became sticky. Sixteen incubation/ hatching tanks were used in this study, each containing $18 \mathrm{~L}$ of freshwater per tank. The experiment was conducted in four replications. The eggs were dispersed in the hatching tanks by a pipette. About $5 \mathrm{ml}$ of egg-containing sample was incubated in each tank. For reference, $1 \mathrm{ml}$ of egg is equivalent to about 644 eggs (each tank has 3220 egg). The water was aerated and the experiment was conducted at the temperature 26.2 $26.38^{\circ} \mathrm{C}$.

Hatching percentage was calculated for each treatment system. The fertilized egg masses were incubated in the spawning tanks for two days. The percentage of hatchlings that emerged following the incubation was estimated over days after fertilization. The density of larvae (number of larvae per tank) was determined in 5 samples (100 ml per sample). The number of larvae was counted in a sample of $100 \mathrm{~m}$ drawn from each tank.

Hatching rate $=\frac{\begin{array}{c}\text { No. of eggs } \\ \text { hatched }\end{array}}{\begin{array}{c}\text { Total no. of eggs in } \\ \text { a batch }\end{array}} \times 100 \ldots .$. Eq. (1)


The survival rate was calculated over seven days by using the equation (2):

$$
\text { Survival rate }=\frac{\begin{array}{c}
\text { No. of live hatchling of } \\
\text { eggs to larval stage }
\end{array}}{\begin{array}{c}
\text { Total no. of } \\
\text { hatchling eggs }
\end{array}} \times 100 \ldots . \text { Eq. (2) }
$$

Statistical software SAS 9.0 was used for the one-way analysis of variance (ANOVA) and Duncan's multiple test was applied to determine the significance of differences among the water properties, hatchability rate and survival rate of African catfish at magnetic intensities of $0.10,0.15$ and 0.20 $\mathrm{T}$. The differences are regarded as significant if $\mathrm{P} \leq 0.05$.

\section{Results and Discussion}

Effect of exposure to magnetic field on water properties Generally, the dissolved oxygen increases with increasing water magnetization. The best result shows an increase of $0.41 \mathrm{mg} \mathrm{L}^{-1}$ after the water was magnetized with field strength of $0.20 \mathrm{~T}$. Constant aeration was necessary to keep the eggs in suspension and to provide sufficient dissolved oxygen to the eggs to aid in their hatching. A minimum of three parts per million dissolved oxygen during the incubation is crucial for the metabolism of the catfish. This result is in agreement with AL-Ibady (2015) who observed that the increase in magnetic intensity led to significant increase in dissolved oxygen concentration compared to normal water (control).

It can be seen from the data that the $\mathrm{pH}$ increased slightly with magnetization intensity. The results show a maximum increase of $0.16 \mathrm{pH}$ after the water was magnetized with field strength of $0.20 \mathrm{~T}$. The exposure of water to magnetic field softens the water and increases the $\mathrm{pH}$ (Lowe, 1996). This is in agreement with Hasaani et al. (2015) although the authors reported a $12 \%$ increase in water $\mathrm{pH}$ after magnetization. The effect depends on the intensity of the magnetic field exposure (AbdelTawab et al, 2011).

Results of these treatments show a significant decrease in $\mathrm{NH}_{4}-\mathrm{N}$ concentration compared to normal water. The lowest decrease of $\mathrm{NH}_{4}-\mathrm{N}$ was recorded from 0.20 to $0.16 \mathrm{mg} \mathrm{L}^{-1}$ after the water was magnetized with a magnetic field strength of $0.20 \mathrm{~T}$. The magnetic field increased the free radical formation, while the reactivity and oxidation potential of those chemical compounds may have reduced the concentration of organic matter contained in the analyzed liquids (Krzemieniewski et al., 2002).

The water salinity showed no significant effect on the trend with magnetization intensity. Browne and Wanigasekera (2000) and Vanhaecke and Sorgeloos (1989) reported that using high intensity of magnetic field lead to decrease in the water salinity.
The total dissolved solids showed no decreasing trend with magnetization intensity. These results are in agreement with those reported by Gilani et al. (2014), Vanhaecke et al. (1984) and Hasaani et al. (2015). Researchers have demonstrated that exposure to magnetic field affects the molecular and physico-chemical properties of water by altering the water nucleus (Hasson and Bramson, 1985; Gehr et al., 1995; Coey and Cass, 2000; Cai, et al., 2009). The water molecules align in one direction due to the relaxation of bonds, and decrease in their angle to below 105을 (Lowe, 1996). The consolidation degree between water molecules decreases which could cause an increase in the size of molecules. This can change the $\mathrm{pH}$ and TDS properties in the water. The results of the current study are in disagreement with AL-Ibady (2015), who observed an increase in the total dissolved solids with increase in exposure to magnetic field intensity. The effect of magnetic water treatment depends on the composition of the treated water, magnetic field strength, rate of water movement, duration of its stay in the magnetic field and other factors. The reason for the increased solubility of the salts when exposed to the magnetic fields is due to the magnetically modified chemical and physical properties of water. Results of water properties

\begin{tabular}{|c|c|c|c|c|}
\hline Treatment & $\begin{array}{c}\text { Normal } \\
\text { water } \\
\text { (control) }\end{array}$ & $0.10 \mathrm{~T}$ & $0.15 \mathrm{~T}$ & $0.20 \mathrm{~T}$ \\
\hline \multirow{2}{*}{$\mathrm{pH}$} & $8.03 \pm$ & $8.13 \pm$ & $8.17 \pm$ & $8.19 \pm$ \\
\hline & $0.03^{c}$ & $0.02^{\mathrm{b}}$ & $0.01^{\mathrm{a}}$ & $0.01^{\mathrm{a}}$ \\
\hline SPC uscm-1 $^{-1}$ & $\begin{array}{c}242.3 \pm \\
4.60^{\mathrm{a}}\end{array}$ & $\begin{array}{c}240.5 \pm \\
0.21^{\mathrm{a}}\end{array}$ & $\begin{array}{c}240.3 \pm \\
0.17^{a}\end{array}$ & $\begin{array}{c}240.2 \pm \\
0.26^{\mathrm{a}}\end{array}$ \\
\hline $\mathrm{CD}_{\mathrm{uscm}^{-1}}$ & $\begin{array}{c}247.55 \pm \\
3.71^{\mathrm{a}}\end{array}$ & $\begin{array}{c}246.75 \pm \\
0.5^{\mathrm{a}}\end{array}$ & $\begin{array}{c}246.85 \pm \\
0.62^{\mathrm{a}}\end{array}$ & $\begin{array}{c}246.38 \pm \\
0.40^{\mathrm{a}}\end{array}$ \\
\hline TDS $\mathrm{mgL}^{-1}$ & $\begin{array}{c}157.3 \pm \\
2.60^{a}\end{array}$ & $\begin{array}{c}156.3 \pm \\
0.38^{\mathrm{a}}\end{array}$ & $\begin{array}{l}156 \pm \\
0.00^{\mathrm{a}}\end{array}$ & $\begin{array}{l}156 \pm \\
0.00^{a}\end{array}$ \\
\hline SAL/ ppt & $\begin{array}{c}0.113 \pm \\
0.01^{\mathrm{a}}\end{array}$ & $\begin{array}{l}0.11 \pm \\
0.00^{\mathrm{a}}\end{array}$ & $\begin{array}{l}0.11 \pm \\
0.00^{a}\end{array}$ & $\begin{array}{l}0.11 \pm \\
0.00^{\mathrm{a}}\end{array}$ \\
\hline $\mathrm{NH}_{4}-\mathrm{NmgL}^{-1}$ & $\begin{array}{l}0.20 \pm \\
0.03 a\end{array}$ & $\begin{array}{l}0.17 \pm \\
0.01^{b}\end{array}$ & $\begin{array}{c}0.17 \pm \\
0.01^{b}\end{array}$ & $\begin{array}{l}0.16 \pm \\
0.01^{b}\end{array}$ \\
\hline $\mathrm{NH}_{3}-\mathrm{NmgL}^{-1}$ & $\begin{array}{l}0.02 \pm \\
0.00^{a}\end{array}$ & $\begin{array}{l}0.02 \pm \\
0.00^{a}\end{array}$ & $\begin{array}{l}0.02 \pm \\
0.00^{a}\end{array}$ & $\begin{array}{l}0.02 \pm \\
0.00^{\mathrm{a}}\end{array}$ \\
\hline DO $\mathrm{mgL}^{-1}$ & $\begin{array}{l}5.92 \pm \\
0.07 \mathrm{c}\end{array}$ & $\begin{array}{l}5.92 \pm \\
0.07 \mathrm{c}\end{array}$ & $\begin{array}{l}6.11 \pm \\
0.08^{b}\end{array}$ & $\begin{array}{l}6.33 \pm \\
0.04^{\mathrm{a}}\end{array}$ \\
\hline Co & $\begin{array}{c}26.20 \pm \\
0.06^{a}\end{array}$ & $\begin{array}{c}26.35 \pm \\
0.00^{a}\end{array}$ & $\begin{array}{c}26.40 \pm \\
0.00^{a}\end{array}$ & $\begin{array}{c}26.38^{\mathrm{a} \pm} \\
0.00^{\mathrm{a}}\end{array}$ \\
\hline
\end{tabular}
in the experimental and control sets are shown in Table 1.

Table 1. Effect of exposure of magnetic field on properties of water magnetized $0.10,0.15$ and $0.20 \mathrm{~T}$.

superscripts in rows are not significantly different according to Duncan's test $\mathrm{P} \leq$ 0.05).

\section{Effect of exposure to magnetic field on hatching percentage}

The exposure of African catfish to magnetic field has a significant effect $(\mathrm{P} \leq 0.05)$ on egg hatchability. Exposure to $0.10,0.15$ and $0.20 \mathrm{~T}$ achieved the hatchability rate of 55.03 , 59.22 and $66.76 \%$, respectively, compared with the hatching rate $51.68 \%$ in the normal water. Environmental factors that may affect egg and sperm quality in fish include the diet of the brood fish and the physiochemical conditions of the water in which the eggs are incubated (temperature, salinity 
and $\mathrm{pH}$ of the water). The hatching process is dependent upon water temperature while the hatching rate is depends on the water quality, oxygen level, temperature, and water hardness (Megbowon et al., 2013). The hatching rate is higher for magnetized water treatments of $0.10,0.15$ and $0.20 \mathrm{~T}$, than the control group (Figure 4). According Formicki et al. (2015), exposure to magnetic field positively affected the fish sperm motility and increased percentage of fertilized eggs by $12.7 \%$ for $1 \mathrm{mT}, 15 \%$ for $10 \mathrm{mT}, 11.4$ for 3 $\mathrm{mT}$, and 22.1 for $1 \mathrm{mT}$ compared to the control. Egg fertilization rates of spermatozoa held for 24 hours under effect magnetic field intensity of $1 \mathrm{mT}$ was: $71.32 \%$ at $5 \mathrm{mT}$ and $59.99 \%$ under the intensity of $10 \mathrm{mT}$. In the control sample, egg fertilization rate was only $32.60 \%$ (Formicki et al., 2013).

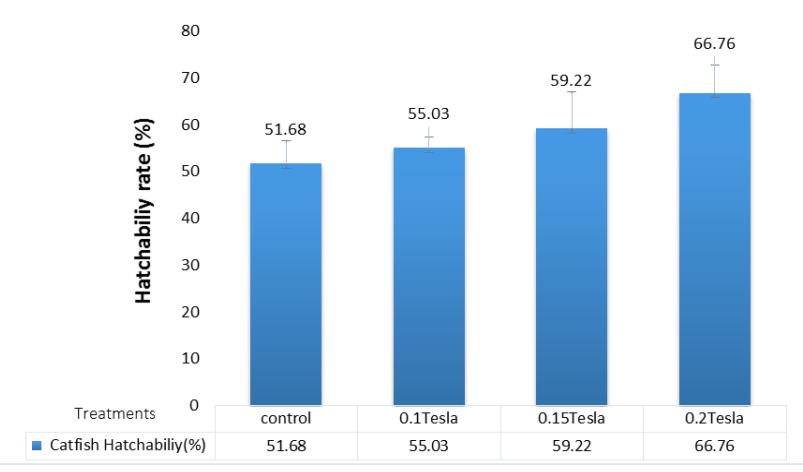

Figure 4. Hatching rate (\%) of African catfish (C.gariepinus) in the normal water (control) and water magnetized 0.10 , 0.15 and $0.20 \mathrm{~T}$.

There were slight differences between the survival of larvae that were exposed to magnetically treated water and those which were not (Figure 5).

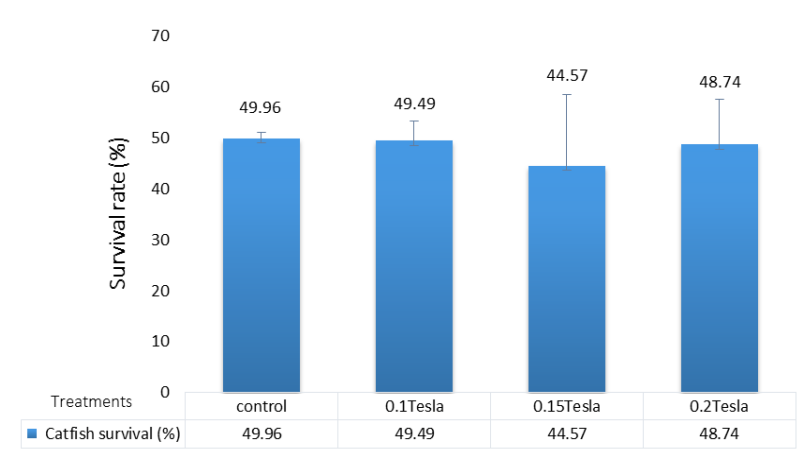

Figure 5. Survival rate (\%) of African catfish (C.gariepinus) in the normal water (control) and water magnetized 0.10 , 0.15 and $0.20 \mathrm{~T}$.

The magnetic field stimulates the breathing process of embryonic Tilapia, thereby enhancing their morphogenesis and thus gastrulation and closing of the blastopore, during organogenesis and development of the blood circulation system (Formicki and Winnicki, 1998).
Table 2 summarizes the effect of magnetized water on the hatching percentage of the catfish. Increases of $6.09 \%$, $12.74 \%$, and $22.59 \%$ in in the hatching rate were attained in water exposed to magnetic field of $0.10,0.15$ and $0.20 \mathrm{~T}$, respectively. The best average hatching result was attained when the water was magnetized with field strength of $0.20 \mathrm{~T}$.

Table 2. Effect of magnetized water hatching rate compared with normal water (\%).

\begin{tabular}{|lccc|}
\hline $\begin{array}{l}\text { Magnetic field } \\
\text { strength }\end{array}$ & $0.10 \mathrm{~T}(\%)$ & $0.15 \mathrm{~T}(\%)$ & $0.20 \mathrm{~T}(\%)$ \\
\hline $\begin{array}{l}\text { Increase of hatching } \\
\text { percentage }\end{array}$ & $6.09 \uparrow$ & $12.74 \uparrow$ & $22.59 \uparrow$ \\
\hline
\end{tabular}

The statistical analysis refers to the effect of magnetized water on the hatching and surviving larvae of the catfish. It can be seen that increase in hatchability is significant $(\mathrm{P} \leq 0.05)$ when the water has been magnetized at $0.20 \mathrm{~T}$, as shown in Table 3 .

Table 3. Effect of the magnetized water on hatching rate and survival rate of larvae.

\begin{tabular}{lcc}
\hline & Number of hatchlings & $\begin{array}{c}\text { Number of surviving } \\
\text { larvae }\end{array}$ \\
\hline Treatment & $6662.00 \pm 616.89 \mathrm{a}$ & $3327.80 \pm 289.10^{\mathrm{a}}$ \\
$0.10 \mathrm{~T}$ & $7092.00 \pm 296.86^{\mathrm{a}}$ & $3510.00 \pm 180.00^{\mathrm{ab}}$ \\
$0.15 \mathrm{~T}$ & $7632.00 \pm 1004.56^{\mathrm{ab}}$ & $3401.80 \pm 632.72^{\mathrm{a}}$ \\
$0.20 \mathrm{~T}$ & $8604.00 \pm 756.28^{\mathrm{b}}$ & $4193.80 \pm 564.45^{\mathrm{b}}$
\end{tabular}

*Same letters in column are not significantly different according to Duncan's test $(\mathrm{P} \leq 0.05)$.

The magnetic field may have increased water penetration through the cell membrane. The cell membrane contains chains of single domain particles linked by microtubule-like strands to mechanically-gated ion channels in the membrane. The magnetic field may tug on the microtubule-like strands to open the channels, allowing water ions to cross the membrane (Kirschvink et al., 2001; Walker et al., 2002).

According to Tyari et al. (2014), magnetic water increases the solubility of minerals which eventually improves the transfer of nutrients to the fish. It can be assumed that improved hatchability of the eggs of $C$. gariepinus is due to the magnetic field influencing the membrane functions through the local effect on ion fluxes, ligand binding and alteration in the distribution and aggregation of the intramembranous proteins (Bersani, 1997).

\section{Conclusion}

Treatments involving the effect of magnetic field of the strengths $0.10,0.15$ and $0.20 \mathrm{~T}$ have demonstrated certain variations in some of the physical and chemical properties of water such as DO (mg L-1), pH, NH $4-\mathrm{N}, \mathrm{SPC}\left(\mathrm{uscm}^{-1}\right), \mathrm{CD}$ $\left(\mathrm{uscm}^{-1}\right)$, and TDS ( $\mathrm{mg} \mathrm{L}^{-1}$ ). Significant increase from 51.68 to $55.03,51.68$ to 59.22 and 51.68 to 66.67 in African catfish 
hatchability rate was attained in water exposed to a magnetic field of $0.10,0.15$ and $0.20 \mathrm{~T}$, respectively. There was only minor effect of exposure to magnetic field on the survival rate of the fish. The most significant hatching rate of $66.76 \%$ was attained when the water was exposed to field strength of $0.20 \mathrm{~T}$ compared to the control where it was $51.68 \%$. Results of this study have positive implications for aquaculture because the higher rate of hatching will increase and economize the fish seed supply for aquaculture.

\section{Acknowledgements}

This study was partially funded by a grant from Universiti Malaysia Perlis (UniMAP); project no. 2016/6129-00001. Gratitude is expressed for technicians Nurul Afidah Binti Umoruddin and Mohammad Sallehhuddin.

\section{References}

Abdel Tawab, Rameen, S., Younes, M. A., Ibrahim, A. M., \& Abdul-Aziz, M. M. (2011). Testing Commercial Water Magnetizers: A Study of TDS and pH. Fifteenth International Water Technology Conference, IWTC, Alexandria, Egypt, 15.

AL-Ibady, Q.A.K. (2015). Influence of the Dipolar magnetized water on the ecological factors of freshwater ostracod Cypris laevis (O. F. Müller, 1776). Journal of Environmental Science, Toxicology and Food Technology 9(9), 09-15.

Ataguba, G.A., Annune, P.A. \& Ogbe, F.G. (2009). Induced breeding and early growth of progeny from crosses between two African clariid fishes, Clarias gariepinus (Burchell) and Heterobranchus longifilis under hatchery conditions. Journal of Applied Biosciences 14, 755-760.

Baker, J.S. \& Judd, S.J. (1996). Magnetic amelioration of scale formation. Water Research 30, 247-260.

Bersani, F., Marinelli, F., Ognibene, A., Matteucci, A., Cecchi, S., Santi, S., Squarzoni, S., \& Maraldi, N. M. (1997). Intramembrane protein distribution in cell cultures is affected by $50 \mathrm{~Hz}$ pulsed magnetic fields. Bioelectromagnetics 18, $463-469$.

Bhatnagar, A. \& Devi, P. (2013). Water quality guidelines for the management of pond fish culture. International Journal of Environmental Sciences 3(6), 1980-2009.

Browne, R. \& Wanigasekera, G. (2000). Combined effects of salinity and temperature on survival and reproduction of five species of Artemia. Journal of Experimental Marine Biology and Ecology 244(1), 29-44.

Cai, R., Yang, H., He, J., \& Zhu, W. (2009). The effects of magnetic fields on water molecular hydrogen bonds. Journal of Molecular Structure 938(1), 15-19.

Chew, G.L. \& Brown, G.E. (1989). Orientation of rainbow trout (Salmo gairdneri) in normal and null magnetic fields. Canadian Journal of Zoology 67(3): 641-643.

Coey, J. \& Cass, S. (2000). Magnetic water treatment. Journal of Magnetism and Magnetic Materials 209 (1), 71-74.

De graaf, G.J., Galemoni, F. \& Banzoussi, B. (1995). The artificial reproduction and fingerling production of the African catfish, Clarias gariepinus (Burchell 1822), in protected and unprotected ponds. Aquaculture Research, 26(4), 233-242.

Formicki, K. \& Perkowski, T. (1998). The effect of a magnetic field on the gas exchange in rainbow trout Oncorhynchus mykiss embryos (Salmonidae). Italian Journal of Zoology 65, 475-477.

Formicki, K., \& Winnicki, A. (1998). Reactions of fish embryos and larvae to constant magnetic fields. Ital. J. Zool., 65, 479-482.
Formicki, K. (2008). Magnetoreception - In: Fish Larval Physiology (Eds.) R.N. Finn, B.G. Kapoor, Science Publisher, USA: 461-491.

Formicki, K., Bonisławska, M. \& Jasinski, M. (1997). Spatial orientation of trout (Salmo trutta L.) and rainbow trout (Oncorhynchus mykiss Walb.) embryos in natural and artificial magnetic field. Acta Ichthyol. Piscat 27, $29-40$.

Formicki, K., Sadowski, M., Tanski, A., Korzelecka-Orkisz, A., \& Winnicki A. (2004b). Behaviour of trout (Salmo trutta L.) larvae and fry in constant magnetic field. Journal of Applied Ichthyology 20(2), 290-294.

Formicki, K., Szulc, J., Orkisz, A., Tanski, A., Kurzydłowski, J., Grzonka, J., \& Kwiatkowski P. (2015). The effect of a magnetic field on trout (Salmo trutta Linnaeus, 1758) sperm motility parameters and fertilisation rate. Journal of Applied Ichthyology 31, 136-146.

Formicki, K., Szulc, J., Tanski, A., Korzelecka-Orkisz, A., Witkowski, A., \& Kwiatkowski P. (2013). The effect of static magnetic field on Danube huchen, Hucho hucho (L.) sperm motility parameters. Arch. Pol. Fish 21, 189-197.

Formicki, K., Tanski, A., Sadowski, M., \& Winnicki, A. (2004a). Effects of magnetic fields on fyke net performance. Journal of Applied Ichthyology 20(5), 402-406.

Gabrielli, C., Jaouhari R., Maurin G. \& Keddam M. (2001). Magnetic water treatment for scale prevention. Water Research 35(13), 3249-3259.

Gehr, R., Zhai, Z. A., Finch, J. A., \& Ram Rao, S. (1995). Reduction of Soluble Miner Concentrations in CaSO4 Saturated Water Using a Magnetic Fields. Water Research 29(3), 933-940.

Gilani, A., Kermanshahi, H., Golian, A., Gholizadeh, M., \& Mohammadpour, A. A. (2014). Assessment of magnetized drinking water on excreta quality, nutrients digestibility, serum components and histomorphology of digestive tract in broiler chickens. Research Opinions in Animal \& Veterinary Sciences 4(3), 120-127.

Gill, A. B., Gloyne - Phillips, I., Neal, K. J., \& Kimber, J. A. (2005). The Potential Effects of Electromagnetic Fields Generated by Sub-Sea Power Cables Associated with Offshore Wind Farm Developments on Electrically and Magnetically Sensitive Marine Organisms- A Review. COWRIE-EM Field 2-06-2004. Cranfield, U.K: Cranfield University.

Hasaani, S., Hadi, Z. \& Rasheed K. (2015). Experimental Study of the Interaction of Magnetic Fields with Flowing Water. International Journal of Basic and Applied Science 03, 1-8.

Hasson, D. \& Bramson D. (1985). Effectiveness of magnetic water treatment in suppressing calcium carbonate scale deposition. Industrial \& Engineering Chemistry Process Design and Development 24(3), 588592.

Hogendoorn, H. (1979). Controlled propagation of the African catfish, Clarias lazera (C \& V).I. Reproductive biology and field experiments. Aquaculture 17(4), 323-333.

Janssen, J., (1985). Elevage du poisson chat africa in Clarias lazera (C\&V) en République centrafricaine: I. Propagation artificielle Document Technique 20, GCD/CAF/007/NET. Food and Agricultural Organisation of the United Nations.

Kirschvink, J.L., Walker, M.M. \& Diebel, C.E. (2001). Magnetite based magnetoreception. Curr Opin Neurobiol 11(4), 462-467.

Krzemieniewski, E. T., Teodorowicz, M., Debowski, M., \& Pesta, J. (2004). Effect of a constant magnetic field on water quality and rearing in European sheatfish Slurs glands L. Larvae. Aqua Research 35, 568-573.

Krzemieniewski, M., Debowski, M., Janczukowicz, W., \& Pesta, J. (2003). Changes of tap water and fish-pond water properties induced by magnetic treatment. Polish Journal of Natural Science 14, 459-474.

Krzemieniewski, M., Dobrzynska, A., Janczukowicz, W., Pesta, J., \& Zielinski, M. (2002). Influence of constant magnetic field on intensity of hydroxyl radicals generation in Fenton's reaction. Chemist, 1, 12-15. 
Lebkowska, M. (1991). Effect of constant magnetic field on the biodegrade ability of organic compounds. Warsaw University of Technology Publishing House. Warsaw. Effect of a Constant Magnetic Field, 53.

Lowe, S., (1996). The Mechanism of the Vortex Water Energy System. Helping Agriculture \& the Environment through the 21st Century, Fluid Energy Australia.

Lund, E.J. (1947). Bioelectric Fields and Growth. Austin, University of Texas Press.

Macharia, S.K., Ngugi C.C. \& Rasowo J. (2005). Comparative Study of Hatching Rates of African Catfish (Clarias gariepinus Burchell 1822) Eggs on Different Substrates. NAGA, World Fish Center Quaterly 28(3 \& 4), 23-26.

Megbowon, I., Fashina-Bombata, H. A, Akinwale, M. M-A, Hammed, A. M, Okunade, O. A., \& Mojekwu, T.0. (2013). Breeding Performance of Clarias Gariepinus Obtained From Nigerian Waters. Journal of Agriculture and Veterinary Science 6(3), 06-09.

Olaleye, V.F. (2005). A review of reproduction and gamete management in the African catfish, Clarias gariepinus (Burchell 1822). Ife Journal of Science 7(1), 63- 70.

Oyeleye, O.O \& Omitogun, O.G. (2007). Evaluation of motility of the short-term cryopreserved sperm of African giant catfish (Clarias gariepinus). Ife Journal of Agriculture 22(1), 11-16.

Rasoolian, M., Takhsha, R., Sarani, O., \& Saravani, Y. (2014). Evaluation of magnetic field on water hardness and some characteristics of concrete. International Research Journal of Applied and Basic Sciences 8, 18861890.

Sadowski, M., Winnicki, A., Formicki, K., Sobocinski A., \& Tanski, A. (2007). The effect of egg shells of salmonid fishes. Acta Ichthyol. Piscat37, 129-135.

Soundarapandian, P., \& Saravanakumar, G. (2009). Effect of Different Salinities on the Survival and Growth of Artemina Spp. Current Research Journal of Biological Sciences 1(2), 20-22.

Sunitha, K., \& Padmavathi, P. (2013). Influence of probiotics on water quality and fish yield in fish ponds. Int. J. Pure. Appl. Sci. Technol 19(2), 48-60.

Tanski, A., Formicki K., Korzelecka-Orkisz A. et al. (2005). Spatial orientation of fish embryos in magnetic field. Electron. J. Ichthyol 1, 21-34.

Tesch, F.W., Wendt T. \& Karlsson L. (1992). Influence of geomagnetism on the activity and orientation of the eel Anguilla anguilla $\mathrm{L}$, as evident from laboratory experiments. Ecology of Freshwater Fish 1(1), 52-60.

Tyari, E., Jamshidi A.R. \& Neisy A. (2014). Magnetic Water and its Benefit in Cattle Breeding, Pisciculture and Poultry. Advances in Environmental Biology 8, 1031-1036.

Vagra, A. (1976). Protein biosynthese bei Mikroorganismen unter Einwirkung von ausseren elektromagnetischen Feldern. VEB Georg Thiem, Leipzig, Germany.

Vanhaecke, P. \& P. Sorgeloos. (1989). International Study on Artemia. XLVII. The effect of temperature on cyst hatching, larval survival and biomass production for different geographical strains of brine shrimp Artemia spp. Ann. Soc. r. zool. Belg. 119(1), 7-23.

Vanhaecke, P., Siddall, S. E., \& Sorgeloos, P. (1984). International study on Artemia. XXXII. Combined effects of temperature and salinity on the survival of Artemia of various geographical origin. Journal of experimental marine Biology and Ecology 80(3), 259-275.

Walker, M.W., Dennis, T.E. \& Kirschvink, J. L. (2002). The magnetic sense and its use in long-distance navigation by animals. Current Opinion in Neurobiology 12, 735-744.

Winnicki, A., Korzelecka-Orkisz, A., Sobocinski, A., Tanski, A., \& Formicki, K. (2004). Effects of the magnetic field on different forms of embryonic locomotor activity of northern pike, Esox lucius L. Acta Ichthyologica Et Piscatoria 34(2), 193-203. 